\title{
Synthesis and structure-activity relationship study of FD-891: importance of the side chain and C8-C9 epoxide for cytotoxic activity against cancer cells
}

\author{
Tomohiro Itagaki ${ }^{1}$, Ayano Kawamata ${ }^{1}$, Miho Takeuchi $^{2}$, Keisuke Hamada ${ }^{2}$, Yoshiharu Iwabuchi ${ }^{1}$, \\ Tadashi Eguchi $^{3}$, Fumitaka Kudo ${ }^{3}$, Takeo Usui ${ }^{2}$ and Naoki Kanoh ${ }^{1}$ \\ Unified synthesis of FD-891 analogs and their structure-activity relationship are described. By using stereoselective allylation/ \\ crotylation and Evans aldol chemistry, six side-chain fragments having different length and terminus were synthesized. These \\ fragments were coupled with a macrolactone fragment, improved synthesis of which was also developed here, to generate \\ FD-891 and five truncated analogs. These synthetic compounds as well as three analogs obtained from fermentation of gene- \\ disrupted Streptomyces graminofaciens mutants were tested for in vitro cytotoxic activity against HeLa cells. As a result, \\ coexistence of the C8-C9 epoxide and side-chain terminus was found to be critical for the cytotoxic activity.
}

The Journal of Antibiotics (2016) 69, 287-293; doi:10.1038/ja.2015.148; published online 27 January 2016

\section{INTRODUCTION}

FD-891 (1) and FD-892 (2) are biogenetically related macrolides isolated from the fermentation broth of Streptomyces graminofaciens A-8890 in $1994 .^{1}$ These planar structures were first proposed as 18-membered macrolides, ${ }^{2}$ but were later reassigned as 16 -membered compounds as shown in Figure $1 .^{3}$ These macrolides have been reported to exhibit various biological activities. ${ }^{1,4,5}$ Among them, FD-891 (1) has been shown to have significant in vitro cytotoxicity against several tumor cell lines in the 10 nanomolar concentration range, whereas the level of cytotoxicity of FD-892 (2) was 100-fold lower. ${ }^{1}$ There are three structural differences between these molecules; that is, FD-891 (1) possesses a C8-C9 epoxide, C10-hydroxyl group and C25 methyl ether, all of which are tailored by post-polyketide synthase enzymes, ${ }^{6,7}$ whereas none of these functional groups are found in FD-892 (2). Although three total syntheses ${ }^{8-10}$ and the preliminary structure-activity relationship data ${ }^{11}$ of FD-891 (1) have been reported, the detailed mode of action of FD-891 (1) as well as the origin of the difference in cytotoxic activity between FD-891 (1) and FD-892 (2) remains unknown.

We have been interested in the chemistry, biology and biogenesis of FD-891 (1). As part of this research, we herein report the unified synthesis of FD-891 analogs, and the structure-activity relationship of these analogs against human cervical carcinoma HeLa cells.

\section{RESULTS AND DISCUSSION}

Recently, we reported a concise and unified strategy for synthesis of the C1-C18 macrolactone fragments of FD-891 and $892(3,6)$ and their analogs $(4,5)$ (Figure 2). ${ }^{12} \mathrm{FD}-891$ macrolactone (3) possesses C1-C5 unsaturated ester and C8-C9 epoxide, both of which are thought to be representative protein-reactive functional groups. ${ }^{13} \mathrm{We}$ speculated that the macrolactone portion is the minimal pharmacophore for cytotoxicity, and thus tested the synthesized macrolactones 3-6 for their in vitro cytotoxicity against HeLa cells. However, contrary to our expectation, none of the macrolactones-including compound 3, which has the correct $\mathrm{C} 7-\mathrm{C} 10$ oxygen functionality-exerted cytotoxic activity ( $\mathrm{IC}_{50}$ (half-maximal inhibitory concentration) values: $>60 \mu \mathrm{M})$ comparable to that of FD-891 (1, 8.1 nM).

These results indicated that the side-chain portion was necessary for FD-891 (1) to exert cytotoxic activity. To determine what functionality and length of the side-chain portion is needed for the biological activity, five truncated derivatives were designed as shown in Scheme 1; that is, the side-chain terminus was deleted in a stepwise manner to generate truncated derivatives 7-11. We anticipated that FD-891 (1) and its truncated derivatives 7-11 would be synthesized via Julia-Kocienski coupling of macrolactone aldehyde 12 and 1-phenyl$1 H$-tetrazol-5-yl (PT) sulfones 13-18, respectively.

The shortest C19-C21 side-chain fragment $\mathbf{1 8}$ was prepared according to the reported procedure ${ }^{14}$ with some modifications. The other fragments 13-17 were synthesized as shown in Scheme 2. To prepare these fragments, we set known aldehyde $19^{15,16}$ as a common starting material. Brown crotylboration ${ }^{17}$ of 19 using $(+)-\mathrm{Ipc}_{2} \mathrm{BOMe}$ and alcohol protection using tert-butyldimethylsilyl chloride (TBSCl) or $p$-methoxybenzyl chloride (PMBCl) afforded TBS ether 21 and PMB ether 22, respectively. For synthesis of the C19-C23 side-chain

${ }^{1}$ Graduate School of Pharmaceutical Sciences, Tohoku University, Sendai, Japan; ${ }^{2}$ Graduate School of Life and Environmental Sciences, University of Tsukuba, Tsukuba, Japan and ${ }^{3}$ Graduate School of Science and Engineering, Tokyo Institute of Technology, Tokyo, Japan

Correspondence: Professor N Kanoh, Graduate School of Pharmaceutical Sciences, Tohoku University, 6-3 Aza-aoba, Aramaki, Aoba-ku, Sendai 980-8578, Miyagi, Japan. E-mail: nkanoh@m.tohoku.ac.jp

Dedicated to Professor Amos B. Smith, III in celebration of his 50 years of contributions to the chemical sciences.

Received 5 December 2015; revised 22 December 2015; accepted 24 December 2015; published online 27 January 2016 


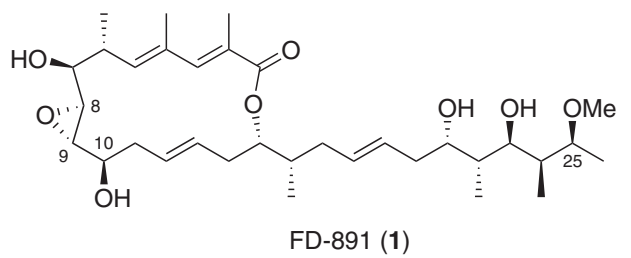

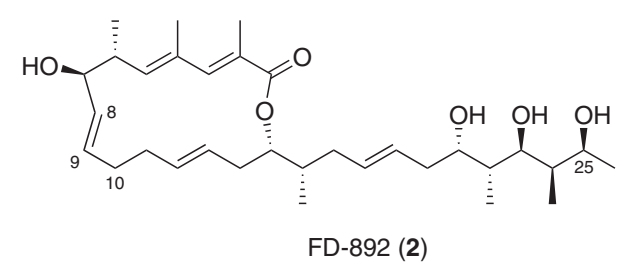

Figure 1 FD-891 and FD-892.

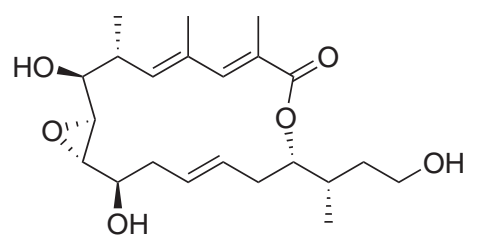

3

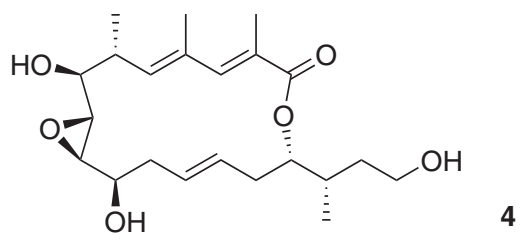

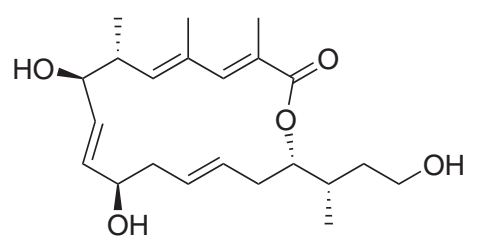

5<smiles>C/C=C(\C)C(=O)O[C@H](C/C=C/CC/C=C\[C@H](O)C(C)C=C(C)CO)[C@H](C)CCO</smiles>

Figure 2 Synthetic macrolactones 3-6.

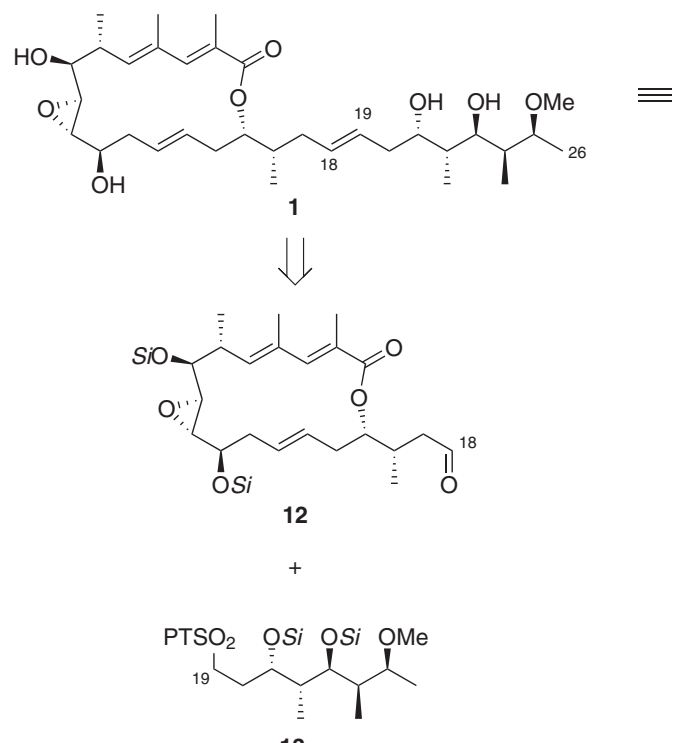

13<smiles>[R]C=CC[C@@H](O)[C@H](O)[C@H](C)[C@H](C)I</smiles>

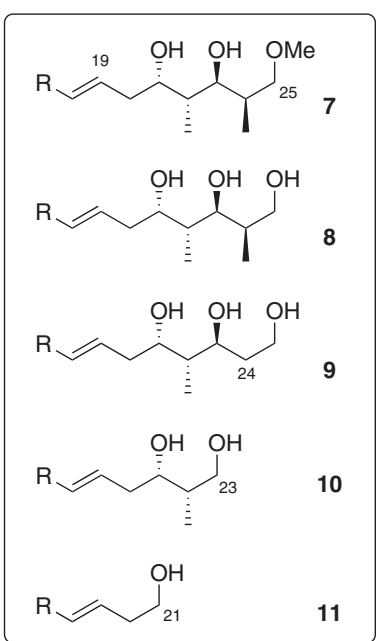
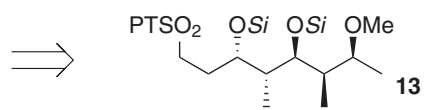

$\mathrm{PTSO}_{2} \quad \mathrm{OSi} \mathrm{OSi} \mathrm{OMe}$
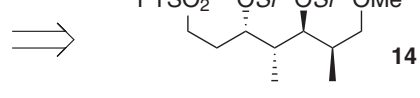

$\mathrm{PTSO}_{2} \quad \mathrm{OSi} \mathrm{OSi} \mathrm{OSi}$
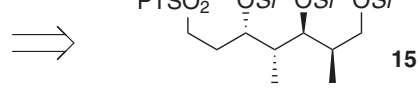

$\mathrm{PTSO}_{2} \quad \mathrm{OSi} \mathrm{OSi} \mathrm{OS}$

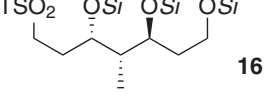

$\mathrm{PTSO}_{2} \quad \mathrm{OSi}$

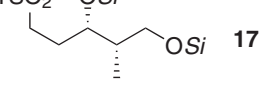

$\mathrm{PTSO}_{2} \mathrm{OSi}$

18

Scheme 1 Design and synthetic strategy of side-chain-truncated derivatives 7-11. PT=1-phenyl-1 H-tetrazol-5-yl; Si=tert-butyldimethylsilyl.

fragment 17, ozonolysis of TBS ether 21 followed by $\mathrm{NaBH}_{4}$ reduction and protection of the resultant primary alcohol ${ }^{16}$ gave bis silylether 24 in $75 \%$ yield over three steps. Hydrogenolysis of benzyl ether, Mitsunobu coupling with 1-phenyl-1H-tetrazole-5-thiol and oxidation of the resultant thioether afforded PT sulfone 17 in $40 \%$ yield over three steps. To make the C19-C25 side-chain fragment $\mathbf{1 6}$ having no methyl group at C24, Lemieux-Johnson oxidation of PMB ether $\mathbf{2 2}$ followed by chelation-controlled stereoseletive allylation using allyltributyltin and $\mathrm{MgBr}_{2}{ }^{18}$ gave homoallyl alcohol 25 in $55 \%$ yield over two steps. Anti-stereochemistry of the 1,3-diol moiety in $\mathbf{2 5}$ was confirmed by ${ }^{13} \mathrm{C}-\mathrm{NMR}$ after converted to the corresponding acetonide. ${ }^{19}$ The subsequent 8 -step procedure including oxidative cleavage of terminal olefin and introduction of PT sulfone afforded the side-chain fragment $\mathbf{1 6}$ in $29 \%$ overall yield.

We expected that C19-C25 fragment 14 and its 25-O-demethyl analog 15 could be synthesized using crotylboration of aldehyde 23 . However, it turned out to be difficult to obtain the desired stereoisomer selectively by crotylboration. ${ }^{20}$ We therefore used Evans aldol 


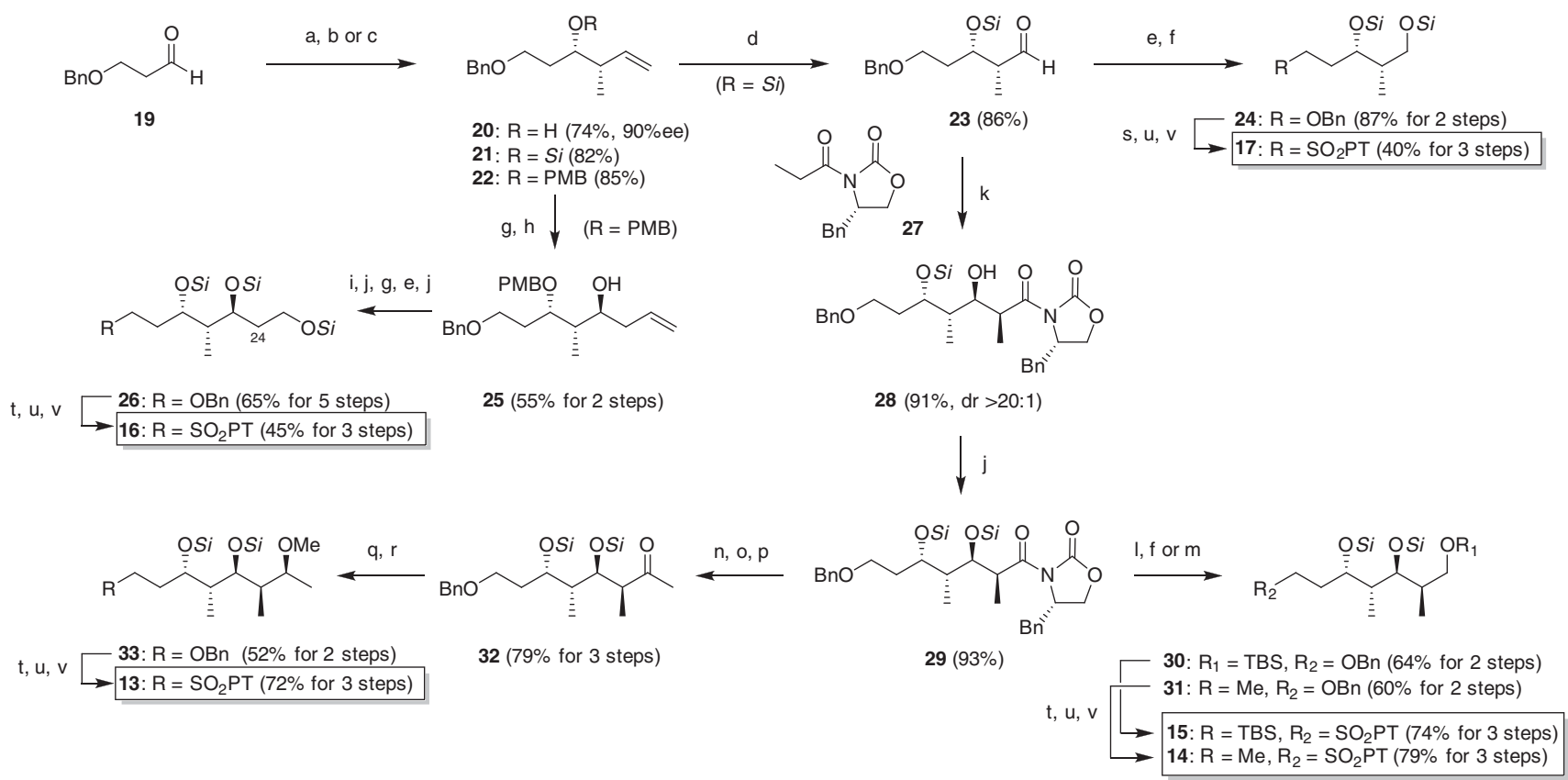

Scheme 2 Synthesis of side-chain fragments 13-17. Reagents and conditions: (a) cis-2-butene, tert-BuOK, n-BuLi, (+)-Ipc $2 \mathrm{BOMe}, \mathrm{BF} \mathrm{B}_{3} \cdot \mathrm{OEt}{ }_{2}, \mathrm{THF}$ (tetrahydrofuran), $-78{ }^{\circ} \mathrm{C}$, then $\mathrm{NaOH}$, aq. $\mathrm{H}_{2} \mathrm{O}_{2}, \mathrm{MeOH}$, room temperature (rt); (b) TBSCl, imidazole, DMF (dimethylformamide), $0^{\circ} \mathrm{C}$ to rt; (c) PMBCl, $\mathrm{NaH}$, DMF, $0{ }^{\circ} \mathrm{C}$ to rt; (d) $\mathrm{O}_{3}, \mathrm{MeOH}_{-} \mathrm{CH}_{2} \mathrm{Cl}_{2},-78{ }^{\circ} \mathrm{C}$, then $\mathrm{PPh}_{3}$; (e) $\mathrm{NaBH}_{4}, \mathrm{MeOH}, 0{ }^{\circ} \mathrm{C}$; (f) $\mathrm{TBSCl}$, imidazole, $\mathrm{CH}_{2} \mathrm{Cl}_{2}, 0^{\circ} \mathrm{C}$; (g) OsO $\mathrm{O}_{4}, \mathrm{NalO}_{4}, 2,6$-lutidine, dioxane- $\mathrm{H}_{2} \mathrm{O}$, rt; (h) allyltributyltin, $\mathrm{MgBr}_{2} \cdot \mathrm{OEt}_{2}, \mathrm{CH}_{2} \mathrm{Cl}_{2}$, rt; (i) TFA, $\mathrm{CH}_{2} \mathrm{Cl}_{2}, \mathrm{O}^{\circ} \mathrm{C}$; (j) TBSOTf, 2,6-lutidine, $\mathrm{CH}_{2} \mathrm{Cl}_{2}, \mathrm{O}^{\circ} \mathrm{C}$; ( $(\mathrm{k})$ oxazolidinone $27, i-\mathrm{Pr}_{2} \mathrm{NEt}^{\circ}$, $\mathrm{CH}_{2} \mathrm{Cl}_{2},-78{ }^{\circ} \mathrm{C}$ to $-50{ }^{\circ} \mathrm{C}$; (I) $\mathrm{LiBH}_{4}, \mathrm{Et}_{2} \mathrm{O}-\mathrm{EtOH}, 0^{\circ} \mathrm{C}$ to rt; (m) MeOTf, proton sponge, $\mathrm{CH}_{2} \mathrm{Cl}_{2}, \mathrm{O}^{\circ} \mathrm{C}$ to rt; (n) LiOH, aq. $\mathrm{H}_{2} \mathrm{O}_{2}, \mathrm{THF}^{\circ} 0^{\circ} \mathrm{C}$ to rt; (o) $\mathrm{NH}(\mathrm{OMe}$ ) $\mathrm{Me} \cdot \mathrm{HCl}, \mathrm{CDI}, \mathrm{CH}_{2} \mathrm{Cl}_{2}$, rt; (p) $\mathrm{MeMgBr}, \mathrm{THF},-20{ }^{\circ} \mathrm{C}$ to rt; (q) $\mathrm{Me}_{2} \mathrm{AlCl}, \mathrm{Bu}_{3} \mathrm{SnH}, \mathrm{CH}_{2} \mathrm{Cl}_{2},-90{ }^{\circ} \mathrm{C}$; (r) $\mathrm{MeOTf}$, proton sponge, $\mathrm{CHCl}_{3}$, reflux; (s) $\mathrm{H}_{2}, \mathrm{Pd} / \mathrm{C}$, $\mathrm{EtOH}$, rt; (t) $\mathrm{H}_{2}, \mathrm{Pd}(\mathrm{OH})_{2} / \mathrm{C}, \mathrm{EtOH}$, rt; (u) 1-phenyl-1 $\mathrm{H}$-tetrazole-5-thiol, $\mathrm{Ph}_{3} \mathrm{P}, \mathrm{DIAD}, \mathrm{THF}, 0{ }^{\circ} \mathrm{C}$ to rt; (v) $\left(\mathrm{NH}_{4}\right)_{6} \mathrm{Mo}_{7} \mathrm{O}_{24} \cdot 4 \mathrm{H}_{2} \mathrm{O}$, aq. $\mathrm{H}_{2} \mathrm{O}_{2}, \mathrm{EtOH}, 0{ }^{\circ} \mathrm{C}$ to rt. Si= tert-butyldimethylsilyl.

chemistry and obtained the coupling product 28 in $91 \%$ yield and good diastereoselectivity. After silylation of the secondary alcohol and subsequent $\mathrm{LiBH}_{4}$ reduction, protection (silylation or methylation) of the resultant primary alcohol gave silylether $\mathbf{3 0}$ and methylether $\mathbf{3 1}$ in $59 \%$ and $56 \%$ combined yields, respectively. Both compounds were successfully converted to the respective PT sulfones 15 and 14 in good overall yields. Fully elaborated C19-C26 fragment 13 was obtained in eight steps from intermediate 29, including diastereoselective reduction ${ }^{11}$ of methyl ketone 32 .

Before coupling of these side-chain fragments with macrolactone 12, the synthetic scheme of 12 was optimized (Scheme 3). Starting from enal $34,{ }^{12}$ organocatalytic allylation using chiral phosphoric acid $35^{21}$ developed by Jain and Antilla afforded homoallyl alcohol 36 in 94\% yield and 93\% ee. Previously, we used Brown allylboration, which requires stoichiometric and air/moisture-sensitive chiral auxiliary, to construct the C10 stereogenic center in our synthesis. Compared with that method, the present Antilla allylboration provides improvements in both catalytic efficiency and practicality. By using our reported 4-step sequence ${ }^{12}$ including vinylogous Mukaiyama aldol reaction using $\mathrm{N}, \mathrm{O}$-ketene silyl acetal 37,22 homoallyl alcohol 36 was converted to amide 38 as a single diastereomer in $86 \%$ overall yield. We previously protected the $\mathrm{C} 7$ alcohol of $\mathbf{3 8}$ as its TBS ether, but selective removal of this TBS group, which was crucial for stereoselective C8-C9 $\alpha$-epoxidation, ${ }^{12}$ in the presence of C10 and C18 TBDPS ethers was difficult, and thus global deprotection followed by C10- and C18-selective protection had to be carried out. In the present case, we selected a more labile TES group for the protection of C7 alcohol, and the amide group of the resulting compound was reduced by diisobutylaluminum hydride (DIBAL-H) to give enal 39 in $87 \%$ yield over two steps. Wittig homologation of $\mathbf{3 9}$ followed by TMSOK (potassium trimethylsilanolate) treatment of the resulting methyl ester afforded $\alpha, \beta, \gamma, \delta$-unsaturated carboxylic acid 41 in $89 \%$ overall yield. Coupling of 41 with alcohol 42 using 2-methyl-6-nitrobenzoic anhydride (MNBA) proceeded smoothly under reflux temperature of $\mathrm{CH}_{2} \mathrm{Cl}_{2}$ to give the desired coupling product in $88 \%$ yield. The requested $\mathrm{C} 7$-selective deprotection was achieved by using catalytic PPTS (pyridinium p-toluenesulfonate) to afford allyl alcohol 43 in $92 \%$ yield. Although Sharpless epoxidation of 43 afforded a 4:1 inseparable mixture of the desired epoxy alcohol 44 and its diastereomer 45 in $70 \%$ combined yield, deprotection of the silyl groups followed by ring-closing metathesis and silica gel separation gave the desired ring-closing metathesis product 46 in 55\% yield over two steps. The present route enabled the synthesis of 46 in 19\% yield from enal 34, which is more than double the yield compared with the previous route ${ }^{12}$ ( $9 \%$ overall yield). Triol 46 was converted to aldehyde 12 via a 3 -step sequence that included oxidation using AZADO (2-azaadamantane $\mathrm{N}$-oxyl) and $\mathrm{CuCl}$ under an $\mathrm{O}_{2}$ atmosphere. ${ }^{23}$ Finally, Julia-Kocienski coupling of aldehyde 12 and PT sulfones 13-18 followed by global deprotection afforded FD-891 (1) and its side-chain-truncated derivatives 7-11, as expected.

Having the natural product and its truncated derivatives in hand, we next evaluated the in vitro cytotoxic activity of these compounds against HeLa cells. In addition to the synthetic samples, compounds obtained by fermentation of gene-disrupted S. graminofaciens A-8890 mutants ${ }^{6,7}$ were also evaluated. These results are listed in Table 1.

25-O-Demethyl-FD-891 (47) ${ }^{7}$ exhibited a fivefold lower level of activity compared with FD-891 (1), whereas the cytotoxic activity of 10-deoxy-FD-891 $(\mathbf{4 8})^{6}$ was almost the same as that of FD-891 (1). 

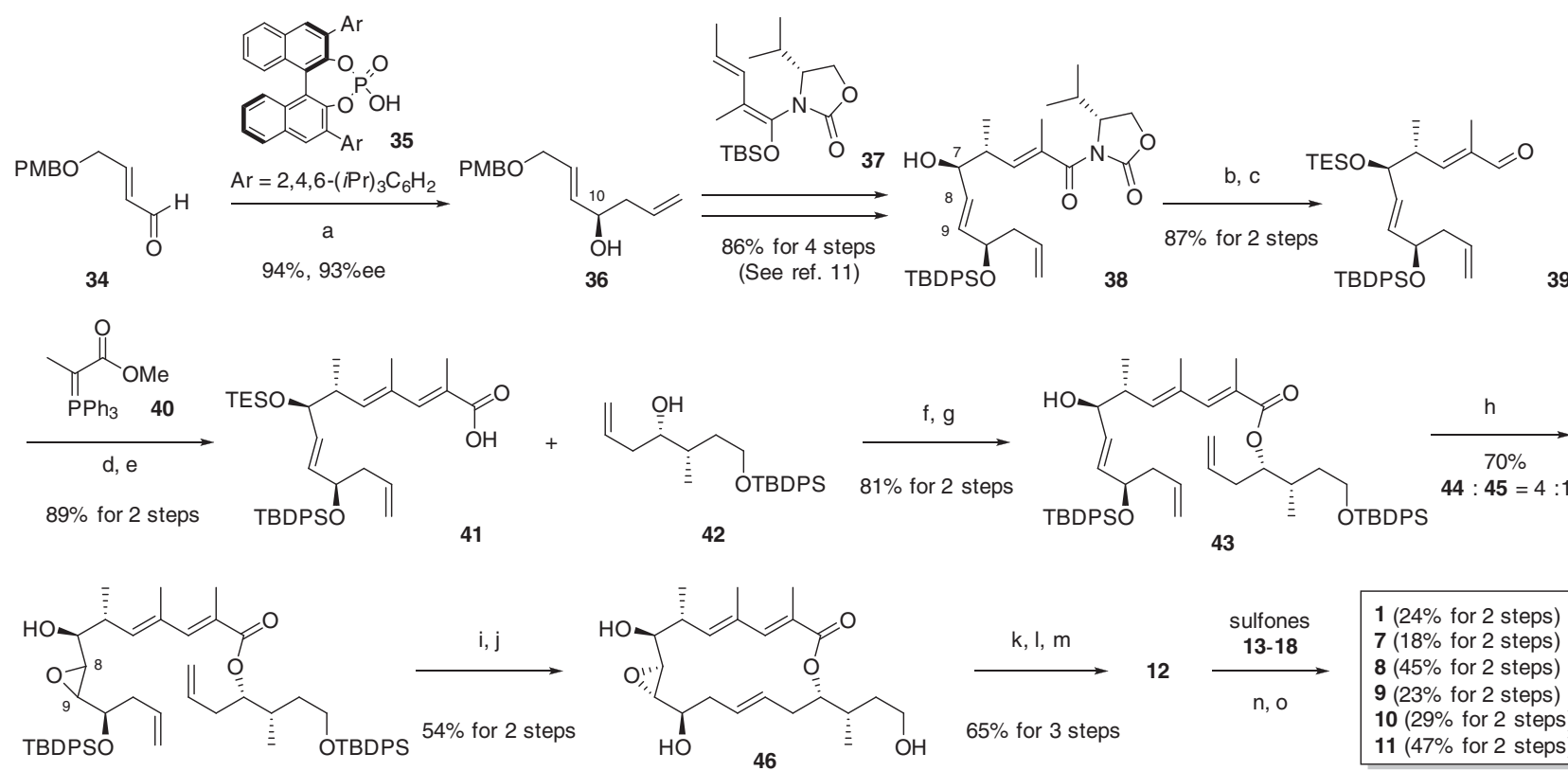

$54 \%$ for 2 steps

44: $C 8, c 9-\alpha$-epoxide

Scheme 3 Synthesis of FD-891 (1) and its side-chain-truncated derivatives 7-11. Reagents and conditions: (a) cat. (R)-TRIP-PA 35, allylpinacolborane, toluene, $-40{ }^{\circ} \mathrm{C}$; (b) TESOTf, 2,6-lutidine, $\mathrm{CH}_{2} \mathrm{Cl}_{2}, \mathrm{O}^{\circ} \mathrm{C}$; (c) DIBAL-H, $\mathrm{CH}_{2} \mathrm{Cl}_{2},-78{ }^{\circ} \mathrm{C}$; (d) Wittig reagent 40, toluene, reflux; (e) TMSOK, THF, rt; (f) MNBA, Et 3 N, DMAP, $\mathrm{CH}_{2} \mathrm{Cl}_{2}$, reflux; (g) PPTS, MeOH, rt; (h) Ti(jOPr) $)_{4}$, (+)-DIPT, TBHP, MS4A, $\mathrm{CH}_{2} \mathrm{Cl}_{2},-25^{\circ} \mathrm{C}$; (i) TBAF, THF, $40{ }^{\circ} \mathrm{C}$; (j) Grubbs secondgeneration catalyst, tetrafluoro-1,4-benzoquinone, $\mathrm{CH}_{2} \mathrm{Cl}_{2}$, reflux; (k) TBSOTf, 2,6-lutidine, $\mathrm{CH}_{2} \mathrm{Cl}_{2}, \mathrm{O}^{\circ} \mathrm{C}$ to rt; (I) PPTS, MeOH, rt; (m) AZADO, $\mathrm{CuCl}$, bpy, DMAP, $\mathrm{CH}_{3} \mathrm{CN}, \mathrm{O}_{2}$, rt; (n) sulfone, KHMDS, DME, $-60{ }^{\circ} \mathrm{C}$; (o) $\mathrm{H}_{2} \mathrm{SiF}_{6}, \mathrm{H}_{2} \mathrm{O}-\mathrm{CH}_{3} \mathrm{CN}$, rt.

These data showed that the presence of C10-hydroxyl group had almost no or even a negative impact on the cytotoxicity, but the C25-O-methyl group seemed to enhance the cytotoxic activity. In sharp contrast to these functional groups, C8-C9 epoxide was found to be critical, as $25-O$-methyl-FD-892 $(49)^{6}$ was more than 800 times less active than FD-891 (1). This result strongly indicated that the coexistence of the side-chain portion and C8-C9 epoxide was crucial because macrolactone 3 was found to be inactive (vide supra). Interestingly, removal of $\mathrm{O}$-methyl from the side-chain terminus had a smaller effect than removal of $C$-methyl (i.e., 47 vs 7 ). We speculated that the length of the carbon side chain was very important. Further removal of C25-O-methyl (8) and C24-methyl (9) did not affect the compound's activity, whereas the more truncated derivatives 10 and 11 lost the cytotoxic activity in a stepwise manner.

In summary, we have synthesized FD-891 (1) and five analogs having a truncated side chain, and carried out a structure-activity relationship study of FD-891 (1) by using nine synthetic compounds and three analogs obtained by the fermentation of gene-disrupted S. graminofaciens mutants. These compounds were evaluated for their in vitro cytotoxic activity against HeLa cells, and the presence of both the side chain and C8-C9 epoxide was found to be critical for the cytotoxicity. Moreover, the length of the side chain and environment of its terminus were also important. It is worth noting that C25 O-methylation and P450-catalyzed C8-C9 epoxidation, two of the three steps of post-polyketide synthase modification in FD-891 biosynthesis, ${ }^{6}$ greatly enhanced the compound's activity, whereas C10 hydroxylation did not improve the activity of the compound. Although the exact role(s) of these functional groups remain to be clarified, the results and derivatives obtained in this study would be useful for further mode-of-action studies. The results obtained from these studies will be reported in due course.

\section{EXPERIMENTAL PROCEDURES}

All reactions were carried out under an argon atmosphere with dehydrated solvents under anhydrous conditions, unless otherwise noted. Dehydrated THF and $\mathrm{CH}_{2} \mathrm{Cl}_{2}$ were purchased from Kanto Chemical Co., Inc. (Tokyo, Japan). Other solvents were dehydrated and distilled according to standard protocols. Reagents were obtained from commercial suppliers and used without further purification, unless otherwise noted. Reactions were monitored by TLC carried out on E Merck Silica gel $60 \mathrm{~F}_{254}$ precoated plates (Merck, Frankfurt, Germany). Column chromatography was performed on Silica gel $60 \mathrm{~N}$ (spherical, neutral, 63-210 $\mu \mathrm{m}$; Kanto Chemical Co., Ltd.) and flash column chromatography was performed on Silica gel $60 \mathrm{~N}$ (spherical, neutral, 40-50 $\mu \mathrm{m}$; Kanto Chemical Co., Ltd.). Optical rotations were measured on a JASCO DIP-370 Digital Polarimeter or JASCO P-2200 Digital Polarimeter (JASCO Corporation, Tokyo, Japan) at room temperature, using the sodium D line. IR spectra were recorded on a JASCO FT/IR-410 Fourier Transform Infrared Spectrophotometer (JASCO Corporation). ${ }^{1} \mathrm{H}-\mathrm{NMR}$ (400 and $600 \mathrm{MHz})$ and ${ }^{13} \mathrm{C}$-NMR spectra $(100$ and $150 \mathrm{MHz})$ were recorded on JEOL JNM-AL-400 and JEOL JNM-ECA-600 spectrometers, respectively (JEOL Resonance Inc., Tokyo, Japan). For ${ }^{1} \mathrm{H}-\mathrm{NMR}$ spectra, chemical shifts $(\delta)$ are given from TMS (0.00 p.p.m.) in $\mathrm{CDCl}_{3}$ as internal standards. For ${ }^{13} \mathrm{C}-\mathrm{NMR}$ spectra, chemical shifts $(\delta)$ are given from $\mathrm{CDCl}_{3}$ (77.0 p.p.m.) as internal standards. The following abbreviations were used to explain the multiplicities: $\mathrm{s}=$ singlet, $\mathrm{d}=$ doublet, $\mathrm{t}=$ triplet, $\mathrm{q}=$ quartet, $\mathrm{m}=$ multiplet, sept $=$ septet and $\mathrm{br}=$ broad. Mass spectra were recorded on a JEOL JMS-DX303, JEOL JNMAL500 and JEOL JMS-700 (JEOL Ltd., Tokyo, Japan).

General procedure for the synthesis of PT sulfones: synthesis of PT sulfone 13

To a solution of precursor sulfide $(69.9 \mathrm{mg}, 0.115 \mathrm{mmol})$ in EtOH $(5.80 \mathrm{ml})$ was added $\left(\mathrm{NH}_{4}\right)_{6} \mathrm{Mo}_{7} \mathrm{O}_{24} \cdot 4 \mathrm{H}_{2} \mathrm{O}(42.5 \mathrm{mg}, 34.4 \mu \mathrm{mol})$ followed by $\mathrm{H}_{2} \mathrm{O}_{2}$ aq. $(0.13 \mathrm{ml}, 8.84 \mathrm{M}, 1.15 \mathrm{mmol})$ at $0{ }^{\circ} \mathrm{C}$. After stirring for $15 \mathrm{~h}$ at room temperature, the reaction mixture was quenched with saturated $\mathrm{Na}_{2} \mathrm{~S}_{2} \mathrm{O}_{3}$ aq. $(10.0 \mathrm{ml})$ and extracted with EtOAc. The combined organic layers were 
Table 1 In vitro cytotoxic activity of FD-891 derivatives against HeLa cells

Compound

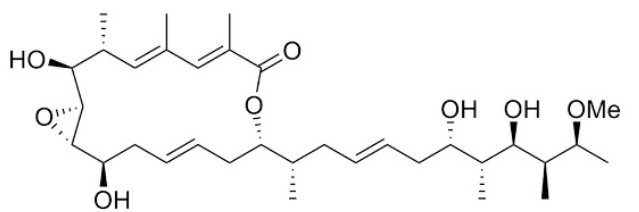

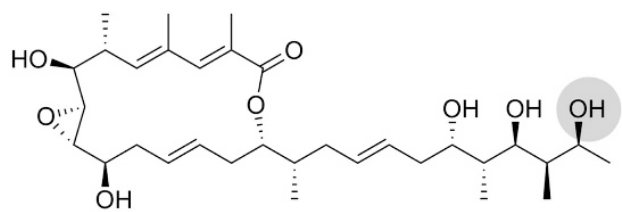

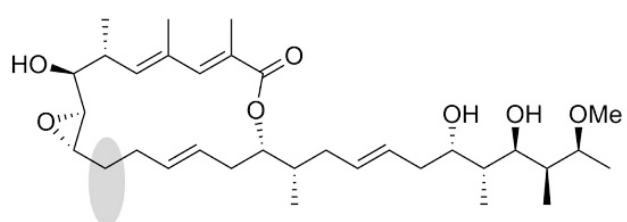

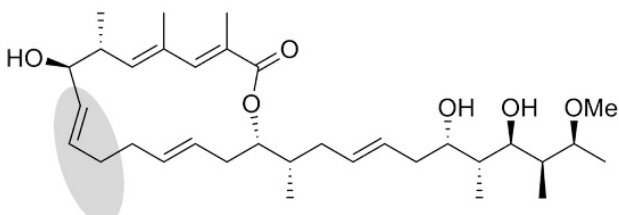

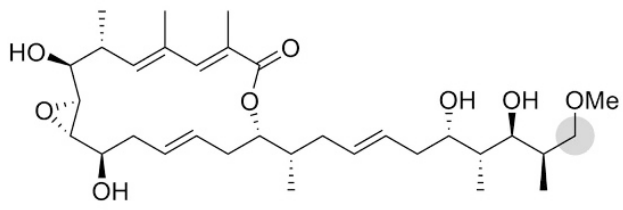

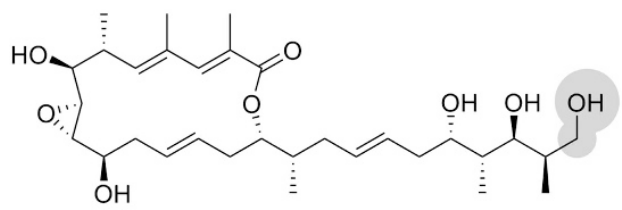

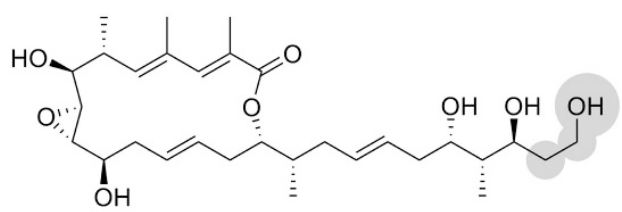

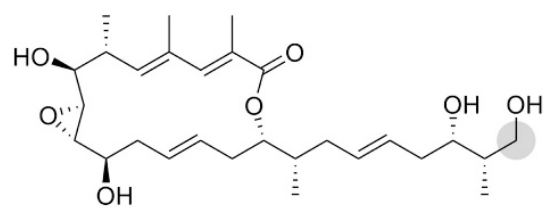

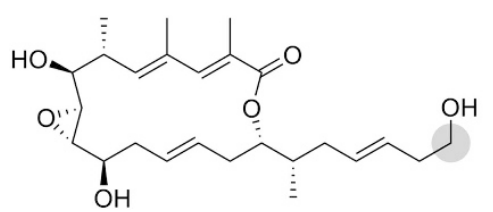

$\mathrm{IC}_{50}(\mu \mathrm{M})$

$0.0081 \pm 0$

FD-891 (1)

25-O-demethyl-FD-891

(47)

$0.044 \pm 0.028$

10-deoxy-FD-891

(48)

25-O-methyl-FD-892

(49)

7

8

9

10

11
$0.0047 \pm 0.0005$

$7.0 \pm 0.1$

$0.16 \pm 0.02$

$0.17 \pm 0.05$

$0.21 \pm 0.10$

$2.4 \pm 0.52$

$42 \pm 1.3$ 
dried over $\mathrm{Na}_{2} \mathrm{SO}_{4}$, and concentrated under reduced pressure. The residue was purified by silica gel column chromatography $(\mathrm{EtOAc} /$ hexane $=1 / 10)$ to give sulfone ( $62.7 \mathrm{mg}, 97.8 \mu \mathrm{mol}, 85 \%)$ as a colorless oil.

13: $[\alpha]^{22} \mathrm{D}+6.4\left(c\right.$ 0.72, $\left.\mathrm{CHCl}_{3}\right)$; IR (neat): $2929 \mathrm{~cm}^{-1} ;{ }^{1} \mathrm{H}-\mathrm{NMR}(400 \mathrm{MHz}$, $\left.\mathrm{CDCl}_{3}\right)$ \& 7.73-7.70 (m, 2H), 7.63-7.57 (m, 3H), 3.89-3.76 (m, 4H), 3.26 (s, 3H), 3.19-3.16 (m, 1H), 2.40-2.31 (m, 1H), 2.21-2.12 (m, 1H), 1.78-1.70 (m, $1 \mathrm{H}), 1.68-1.61(\mathrm{~m}, 1 \mathrm{H}), 1.12(\mathrm{~d}, J=6.0 \mathrm{~Hz}, 3 \mathrm{H}), 0.96(\mathrm{~d}, J=6.8 \mathrm{~Hz}, 3 \mathrm{H})$, $0.93(\mathrm{~d}, J=6.8 \mathrm{~Hz}, 3 \mathrm{H}), 0.91(\mathrm{~s}, 9 \mathrm{H}), 0.90(\mathrm{~s}, 9 \mathrm{H}), 0.110(\mathrm{~s}, 3 \mathrm{H}), 0.107(\mathrm{~s}, 3 \mathrm{H})$, $0.095(\mathrm{~s}, 3 \mathrm{H}), 0.08(\mathrm{~s}, 3 \mathrm{H}) ;{ }^{13} \mathrm{C}-\mathrm{NMR}\left(100 \mathrm{MHz}, \mathrm{CDCl}_{3}\right) \delta 153.5,133.1,131.4$, 129.7, 125.0, 79.6, 72.0, 71.1, 56.2, 51.9, 43.9, 41.2, 27.2, 26.0, 25.9, 18.4, 18.1, $15.7,12.5,11.4,-3.3,-4.1,-4.27,-4.33$; HR-MS (ESI) calcd. for $\mathrm{C}_{30} \mathrm{H}_{57} \mathrm{~N}_{4} \mathrm{O}_{5} \mathrm{SSi}_{2}\left[\mathrm{M}^{+}+\mathrm{H}\right]$ 641.3583, found 641.3568.

\section{PT sulfone 14}

$[\alpha]{ }^{19}{ }_{\mathrm{D}}+1.2$ (c $0.80, \mathrm{CHCl}_{3}$ ); IR (neat): $2955 \mathrm{~cm}^{-1} ;{ }^{1} \mathrm{H}-\mathrm{NMR}(600 \mathrm{MHz}$, $\left.\mathrm{CDCl}_{3}\right) \delta$ 7.72-7.70 (m, 2H), 7.64-7.58 (m, 3H), 3.94-3.93 (m, 1H), 3.85-3.76 $(\mathrm{m}, 3 \mathrm{H}), 3.28(\mathrm{~s}, 3 \mathrm{H}), 3.19$ (dd, $J=8.7,8.7 \mathrm{~Hz}, 1 \mathrm{H}), 3.10(\mathrm{dd}, J=9.0,5.4 \mathrm{~Hz}$, $1 \mathrm{H}), 2.36-2.30(\mathrm{~m}, 1 \mathrm{H}), 2.16-2.10(\mathrm{~m}, 1 \mathrm{H}), 1.79-1.73(\mathrm{~m}, 1 \mathrm{H}), 1.73-1.67$ $(\mathrm{m}, 1 \mathrm{H}), 0.98(\mathrm{~d}, J=7.2 \mathrm{~Hz}, 3 \mathrm{H}), 0.912$ (s, 9H), 0.906 (s, 9H), 0.86 $(\mathrm{d}, J=7.2 \mathrm{~Hz}, 3 \mathrm{H}), 0.11-0.08(\mathrm{~m}, 12 \mathrm{H}) ;+++++{ }^{13} \mathrm{C}-\mathrm{NMR}\left(150 \mathrm{MHz}, \mathrm{CDCl}_{3}\right)$ o 153.4, 133.1, 131.4, 129.7, 125.0, 76.4, 71.6, 70.9, 58.6, 51.7, 43.9, 35.5, 29.7, 27.1, 26.0, 25.9, 18.3, 18.1, 12.4, 11.7, - 3.8, - 4.1, - 4.4, - 4.6; LR-MS (EI) $\mathrm{m} / \mathrm{z}$ $569\left(\mathrm{M}^{+}{ }_{-}{ }^{\mathrm{Bu}}\right), 117(100 \%)$; HR-MS (EI) calcd. for $\mathrm{C}_{25} \mathrm{H}_{45} \mathrm{~N}_{4} \mathrm{O}_{5} \mathrm{SSi}_{2}\left(\mathrm{M}^{+}{ }_{-}{ }^{\mathrm{Bu}}\right)$ 569.2644, found 569.2669 .

\section{PT sulfone 15}

$[\alpha]^{18}{ }_{\mathrm{D}}-0.30$ (c $0.31, \mathrm{CHCl}_{3}$ ); IR (neat): $2928 \mathrm{~cm}^{-1} ;{ }^{1} \mathrm{H}-\mathrm{NMR}(600 \mathrm{MHz}$, $\left.\mathrm{CDCl}_{3}\right) \delta 7.70(\mathrm{dd}, J=8.4,1.8 \mathrm{~Hz}, 2 \mathrm{H}), 7.62-7.59(\mathrm{~m}, 3 \mathrm{H}), 3.88(\mathrm{~m}, 1 \mathrm{H})$, $3.87-3.84(\mathrm{~m}, 1 \mathrm{H}), 3.82-3.80(\mathrm{~m}, 2 \mathrm{H}), 3.44(\mathrm{dd}, J=9.6,8.2 \mathrm{~Hz}, 1 \mathrm{H}), 3.37(\mathrm{dd}$, $J=9.6,6.6 \mathrm{~Hz}, 1 \mathrm{H}), 2.31-2.25(\mathrm{~m}, 1 \mathrm{H}), 2.18-2.12(\mathrm{~m}, 1 \mathrm{H}), 1.73-1.68(\mathrm{~m}, 2 \mathrm{H})$, 0.94 (d, J=7.2 Hz, 3H), 0.903 (s, 9H), 0.899 (s, 9H), 0.87 (s, 9H), 0.84 (d, $J=6.6 \mathrm{~Hz}, 3 \mathrm{H}), 0.11-0.09(\mathrm{~m}, 12 \mathrm{H}), 0.02-0.01(\mathrm{~m}, 6 \mathrm{H}) ;{ }^{13} \mathrm{C}-\mathrm{NMR}(150 \mathrm{MHz}$, $\left.\mathrm{CDCl}_{3}\right) \delta 153.5,131.4,129.7,125.0,71.6,70.9,66.6,51.8,43.5,38.3,29.7,27.4$, $26.02,25.96,25.9,18.4,18.1,12.3,11.3,-3.6,-4.1,-4.3,-4.4,-5.3,-5.4$; LR-MS (EI) $m / z 669\left(\mathrm{M}^{+}{ }_{-} \mathrm{Bu}\right), 117 \quad(100 \%)$; HR-MS (EI) calcd. for $\mathrm{C}_{30} \mathrm{H}_{57} \mathrm{~N}_{4} \mathrm{O}_{5} \mathrm{SSi}_{3}\left(\mathrm{M}^{+}{ }_{-}{ }^{\mathrm{Bu}}\right)$ 669.3352, found 669.3357.

\section{PT sulfone 16}

$[\alpha]^{24}{ }_{D}-7.5$ (c $0.72, \mathrm{CHCl}_{3}$ ); IR (neat): $2954 \mathrm{~cm}^{-1} ;{ }^{1} \mathrm{H}-\mathrm{NMR}(400 \mathrm{MHz}$, $\left.\mathrm{CDCl}_{3}\right) \delta$ 7.72-7.70 (m, 2H), 7.65-7.57 (m, 3H), 3.93-3.89 (m, 1H), $3.83(\mathrm{dd}$, $J=9.6,7.2 \mathrm{~Hz}, 2 \mathrm{H}), 3.76-3.71(\mathrm{~m}, 2 \mathrm{H}), 3.64(\mathrm{dt}, J=9.6,7.2 \mathrm{~Hz}, 1 \mathrm{H}), 2.21-2.15$ $(\mathrm{m}, 2 \mathrm{H}), 1.74-1.69(\mathrm{~m}, 1 \mathrm{H}), 1.65-1.57(\mathrm{~m}, 1 \mathrm{H}), 1.51-1.43(\mathrm{~m}, 1 \mathrm{H}), 0.95$ (d, $J=6.8 \mathrm{~Hz}, 3 \mathrm{H}), 0.91$ (s, 9H), 0.89 (s, 9H), 0.87 (s, 9H), 0.11 (s, 3H), 0.10 $(\mathrm{m}, 6 \mathrm{H}), 0.08(\mathrm{~s}, 3 \mathrm{H}), 0.04(\mathrm{~s}, 6 \mathrm{H}) ;{ }^{13} \mathrm{C}-\mathrm{NMR}\left(100 \mathrm{MHz}, \mathrm{CDCl}_{3}\right) \delta 153.5$, $133.1,131.4,129.7,125.0,71.6,69.2,60.3,51.7,43.4,35.3,26.9,26.0,25.9$, $25.8,18.3,18.1,18.0,11.0,-4.18,-4.22,-4.5,-4.6,-5.3$; HR-MS (ESI) calcd. for $\mathrm{C}_{33} \mathrm{H}_{65} \mathrm{~N}_{4} \mathrm{O}_{5} \mathrm{SSi}_{3}\left(\mathrm{M}^{+}+\mathrm{H}\right) 713.3978$, found 713.3974.

\section{PT sulfone 17}

$[\alpha]^{27} \mathrm{D}+3.40\left(\right.$ c 1.22, $\left.\mathrm{CHCl}_{3}\right)$; IR (neat): $2929 \mathrm{~cm}^{-1}$; ${ }^{1} \mathrm{H}-\mathrm{NMR}(400 \mathrm{MHz}$, $\left.\mathrm{CDCl}_{3}\right): \delta 7.71-7.69(\mathrm{~m}, 2 \mathrm{H}), 7.63-7.57(\mathrm{~m}, 3 \mathrm{H}), 3.91(\mathrm{q}, J=5.4 \mathrm{~Hz}, 1 \mathrm{H}), 3.83$ (ddd, $J=14.6,11.2,5.9 \mathrm{~Hz}, 1 \mathrm{H}), 3.74$ (ddd, $J=14.1,10.7,5.4 \mathrm{~Hz}, 1 \mathrm{H}$ ), 3.56-3.49 (m, 2H), 2.20-2.07 (m, 2H), 1.72-1.66 (m, 1H), 0.91-0.87 $(\mathrm{m}, 21 \mathrm{H}), 0.08(\mathrm{~s}, 3 \mathrm{H}), 0.07(\mathrm{~s}, 3 \mathrm{H}), 0.03(\mathrm{~s}, 6 \mathrm{H}) ;{ }^{13} \mathrm{C}-\mathrm{NMR}(100 \mathrm{MHz}$, $\left.\mathrm{CDCl}_{3}\right): \delta 153.5,133.1,131.4,129.7,125.0,71.1,64.3,53.1,40.6,26.6,25.9$, $25.8,18.2,18.1,12.2,-4.4,-4.6,-5.4,-5.5$; LR-MS (FAB) $\mathrm{m} / z 555.3$ $\left(\mathrm{M}^{+}+\mathrm{H}\right)$, 73.1 (100\%); HR-MS (FAB) calcd. for $\mathrm{C}_{25} \mathrm{H}_{47} \mathrm{~N}_{4} \mathrm{O}_{4} \mathrm{SSi}_{2}\left(\mathrm{M}^{+}+\mathrm{H}\right)$ 555.2851, found 555.2859.

\section{Synthesis of aldehyde 12}

To a solution of precursor alcohol $(23.0 \mathrm{mg}, 37.0 \mu \mathrm{mol})$, AZADO $(0.56 \mathrm{mg}$, $3.7 \mu \mathrm{mol})$, bpy $(0.58 \mathrm{mg}, 3.7 \mu \mathrm{mol})$ and DMAP $(0.90 \mathrm{mg}, 7.40 \mu \mathrm{mol})$ in $\mathrm{MeCN}$ $(1.90 \mathrm{ml})$ was added $\mathrm{CuCl}(0.73 \mathrm{mg}, 7.4 \mu \mathrm{mol})$ at room temperature. After stirring for $15 \mathrm{~min}$ under an $\mathrm{O}_{2}$ atmosphere, the reaction mixture was quenched with saturated $\mathrm{NaHCO}_{3}$ aq. $(5.0 \mathrm{ml})$ and extracted with EtOAc.
The combined organic layers were dried over $\mathrm{MgSO}_{4}$, and concentrated under reduced pressure. The residue was purified by silica gel column chromatography $(\mathrm{EtOAc} / \mathrm{hexane}=1 / 10)$ to give aldehyde $(20.9 \mathrm{mg}, 33.6 \mu \mathrm{mol}, 91 \%)$ as a colorless oil. The aldehyde was immediately used for the next step.

\section{General procedure for the synthesis of FD-891 and its truncated analogs: synthesis of FD-891 (1)}

To a solution of sulfone $\mathbf{1 3}(30.1 \mathrm{mg}, 46.9 \mu \mathrm{mol})$ and crude aldehyde $(8.85 \mathrm{mg}$, $14.3 \mu \mathrm{mol})$ in DME $(1.4 \mathrm{ml})$ was added KHMDS $(94 \mu \mathrm{l}, 0.5 \mathrm{M}$ solution in toluene, $46.9 \mu \mathrm{mol}$ ) at $-60^{\circ} \mathrm{C}$. After stirring for $20 \mathrm{~min}$, the reaction mixture was quenched with saturated $\mathrm{NH}_{4} \mathrm{Cl}$ aq. $(3.0 \mathrm{ml})$ and extracted with EtOAc. The combined organic layers were dried over $\mathrm{Na}_{2} \mathrm{SO}_{4}$, and concentrated under reduced pressure. The residue was purified by silica gel column chromatography $($ EtOAc/hexane $=1 / 20)$ to give coupling adduct $(8.11 \mathrm{mg}, 7.83 \mu \mathrm{mol}$, $55 \%)$ as a colorless oil.

To a solution of coupling adduct $(5.19 \mathrm{mg}, 5.01 \mu \mathrm{mol})$ in $\mathrm{MeCN}(0.6 \mathrm{ml})$ was added fluorosilic acid $40-45 \mathrm{wt} \%$ solution in water $(0.100 \mathrm{ml})$ at room temperature. After stirring for $4 \mathrm{~h}$, the reaction mixture was quenched with saturated $\mathrm{NaHCO}_{3}$ aq. $(5.0 \mathrm{ml})$ and extracted with EtOAc. The combined organic layers were dried over $\mathrm{Na}_{2} \mathrm{SO}_{4}$, and concentrated under reduced pressure. The residue was purified by silica gel column chromatography (EtOAc) to give FD-891 (1) $(1.25 \mathrm{mg}, 2.16 \mu \mathrm{mol}, 43 \%)$ as a colorless oil.

1: $[\alpha]^{22} \mathrm{D}+4.9$ (c 0.080, MeOH); IR (neat): $3446(\mathrm{br}), 1697 \mathrm{~cm}^{-1} ;{ }^{1} \mathrm{H}-\mathrm{NMR}$ $\left(600 \mathrm{MHz}, \mathrm{CDCl}_{3}\right): \delta 7.30(\mathrm{~s}, 1 \mathrm{H}), 5.77(\mathrm{ddd}, J=15.0,10.2,4.8 \mathrm{~Hz}, 1 \mathrm{H})$, 5.63-5.49 (m, 4H), $4.84(\mathrm{dt}, J=9.6,3.6 \mathrm{~Hz}, 1 \mathrm{H}), 4.15$ (brs, $1 \mathrm{H}), 4.00(\mathrm{~s}, 1 \mathrm{H})$, 3.86 (brs, $1 \mathrm{H}), 3.82$ (dd, $J=9.6,1.2 \mathrm{~Hz}, 1 \mathrm{H}), 3.62-3.58(\mathrm{~m}, 2 \mathrm{H}), 3.34(\mathrm{~s}, 3 \mathrm{H})$, 3.25 (dd, $J=4.8,3.0 \mathrm{~Hz}, 1 \mathrm{H}), 3.16(\mathrm{dd}, J=1.8,1.8 \mathrm{~Hz}, 1 \mathrm{H}), 3.12$ (ddd, $J=11.4$, 7.8, 3.6 Hz, 1H), 2.87 (brs, $1 \mathrm{H}), 2.56-2.45(\mathrm{~m}, 3 \mathrm{H}), 2.33-2.17$ (m, 4H), 2.09 (s, 3H), $2.03(\mathrm{~s}, 3 \mathrm{H}), 2.01-1.94(\mathrm{~m}, 2 \mathrm{H}), 1.91-1.81(\mathrm{~m}, 3 \mathrm{H}), 1.19(\mathrm{~d}, J=6.0 \mathrm{~Hz}$, $3 \mathrm{H}), 1.14(\mathrm{~d}, J=7.8 \mathrm{~Hz}, 3 \mathrm{H}), 0.93(\mathrm{~d}, J=7.2 \mathrm{~Hz}, 3 \mathrm{H}), 0.91(\mathrm{~d}, J=6.6 \mathrm{~Hz}, 3 \mathrm{H})$, 0.79 (d, $J=7.8 \mathrm{~Hz}, 3 \mathrm{H}) ;{ }^{13} \mathrm{C}-\mathrm{NMR}\left(150 \mathrm{MHz}, \mathrm{CDCl}_{3}\right): \delta 168.8,144.0,141.7$, $135.8,130.2,129.4,129.3,128.1,124.7,82.7,78.4,76.5,73.2,71.0,70.9,56.0$, $55.9,55.0,39.7,39.6,38.2,36.8,36.0,35.9,34.5,34.4,16.5,16.4,16.3,15.6$, 13.7, 11.6, 4.9; HR-MS (ESI) calcd. for $\mathrm{C}_{33} \mathrm{H}_{55} \mathrm{O}_{8}\left[\mathrm{M}^{+}+\mathrm{H}\right]$ 579.3891, found 579.3878 .

\section{Truncated analog 7}

$[\alpha]^{28}{ }_{\mathrm{D}}-26$ (c $0.080, \mathrm{CHCl}_{3}$ ); IR (neat): 3421 (br), $1696 \mathrm{~cm}^{-1} ;{ }^{1} \mathrm{H}-\mathrm{NMR}$ $\left(400 \mathrm{MHz}, \mathrm{CDCl}_{3}\right): \delta 7.30(\mathrm{~s}, 1 \mathrm{H}), 5.76(\mathrm{ddd}, J=15.2,9.6,5.2 \mathrm{~Hz}, 1 \mathrm{H})$, $5.62-5.48(\mathrm{~m}, 4 \mathrm{H}), 4.84(\mathrm{dt}, J=9.2,3.6 \mathrm{~Hz}, 1 \mathrm{H}), 4.15$ (brs, $1 \mathrm{H}), 3.88$ (d, $J=8.8 \mathrm{~Hz}, 1 \mathrm{H}), 3.82$ (dd, J=9.6, $2.0 \mathrm{~Hz}, 1 \mathrm{H}), 3.60$ (brs, $1 \mathrm{H}$ ), 3.47 (d, $J=4.8 \mathrm{~Hz}, 2 \mathrm{H}), 3.37-3.35(\mathrm{~m}, 4 \mathrm{H}), 3.25(\mathrm{dd}, J=4.8,2.4 \mathrm{~Hz}, 1 \mathrm{H}), 3.15$ (dd, $J=2.0,2.0 \mathrm{~Hz}, 1 \mathrm{H}), 3.14-3.10(\mathrm{~m}, 1 \mathrm{H}), 2.72$ (brs, $1 \mathrm{H}), 2.56-2.28(\mathrm{~m}, 3 \mathrm{H})$, 2.27-2.17 (m, 4H), $2.09(\mathrm{~s}, 3 \mathrm{H}), 2.02(\mathrm{~s}, 3 \mathrm{H}), 1.99-1.82(\mathrm{~m}, 6 \mathrm{H}), 1.14$ $(\mathrm{d}, J=7.2 \mathrm{~Hz}, 3 \mathrm{H}), 0.97(\mathrm{~d}, J=7.2 \mathrm{~Hz}, 3 \mathrm{H}), 0.91(\mathrm{~d}, J=6.4 \mathrm{~Hz}, 3 \mathrm{H}), 0.83$ (d, $J=7.2 \mathrm{~Hz}, 3 \mathrm{H}) ;{ }^{13} \mathrm{C}-\mathrm{NMR}\left(100 \mathrm{MHz}, \mathrm{CDCl}_{3}\right)$ : $\delta 168.8,144.0,141.7,135.8$, $130.0,129.9,129.2,128.1,124.6,78.2,76.4,76.0,73.4,71.0,70.9,59.2,55.9$, $55.1,39.3,38.2,36.6,36.1,35.9,35.2,34.54,34.47,16.5,16.3,15.6,13.7,11.7$, 9.7; HR-MS (ESI) calcd. for $\mathrm{C}_{32} \mathrm{H}_{53} \mathrm{O}_{8}\left[\mathrm{M}^{+}+\mathrm{H}\right] 565.3735$, found 565.3724 .

\section{Truncated analog 8}

$[\alpha]^{28}-21$ (c $0.23, \mathrm{CHCl}_{3}$ ); IR (neat): 3407 (br), $1680 \mathrm{~cm}^{-1} ;{ }^{1} \mathrm{H}-\mathrm{NMR}$ $\left(400 \mathrm{MHz}, \mathrm{CDCl}_{3}\right): \delta 7.30(\mathrm{~s}, 1 \mathrm{H}), 5.76(\mathrm{ddd}, J=15.2,9.6,5.2 \mathrm{~Hz}, 1 \mathrm{H})$, 5.63-5.48 (m, 4H), 4.85 (dt, J=9.2, $3.6 \mathrm{~Hz}, 1 \mathrm{H}), 4.15$ (brs, $1 \mathrm{H}), 3.91-3.88$ $(\mathrm{m}, 2 \mathrm{H}), 3.79(\mathrm{dd}, J=10.8,4.0 \mathrm{~Hz}, 1 \mathrm{H}), 3.71(\mathrm{dd}, J=10.8,5.6 \mathrm{~Hz}, 1 \mathrm{H}), 3.65-$ $3.60(\mathrm{~m}, 2 \mathrm{H}), 3.24(\mathrm{dd}, J=4.8,2.8 \mathrm{~Hz}, 1 \mathrm{H}), 3.15(\mathrm{dd}, J=2.0,2.0 \mathrm{~Hz}, 1 \mathrm{H})$, 3.13-3.10 (m, 1H), 2.56-2.43 (m, 4H), 2.33-2.17 (m, 5H), $2.08(\mathrm{~s}, 3 \mathrm{H}), 2.02$ (s, 3H), 2.00-1.90 (m, 5H), 1.80-1.74 (m, 1H), 1.13 (d, J=7.2 Hz, 3H), 0.99 (d, $J=7.2 \mathrm{~Hz}, 3 \mathrm{H}), 0.91$ (d, $J=7.2 \mathrm{~Hz}, 3 \mathrm{H}), 0.83(\mathrm{~d}, J=7.2 \mathrm{~Hz}, 3 \mathrm{H}) ;{ }^{13} \mathrm{C}-\mathrm{NMR}$ $\left(100 \mathrm{MHz}, \mathrm{CDCl}_{3}\right): \delta 168.9,144.2,141.7,135.8,130.9,129.4,129.1,128.3$, $124.5,76.2,76.1,73.7,71.0,70.9,67.9,55.9,55.1,39.1,38.2,36.4,36.1,35.9$, $34.6,34.5,16.5,16.3,15.6,13.6,11.8,9.1$; HR-MS (ESI) calcd. for $\mathrm{C}_{31} \mathrm{H}_{51} \mathrm{O}_{8}$ $\left[\mathrm{M}^{+}+\mathrm{H}\right]$ 551.3578, found 551.3569. 


\section{Truncated analog 9}

$[\alpha]^{27} \mathrm{D}-20\left(c\right.$ 0.12, $\mathrm{CHCl}_{3}$ ); IR (neat): 3389 (br), $1693 \mathrm{~cm}^{-1} ;{ }^{1} \mathrm{H}-\mathrm{NMR}$ $\left(400 \mathrm{MHz}, \mathrm{CDCl}_{3}\right): \delta 7.30(\mathrm{~s}, 1 \mathrm{H}), 5.76(\mathrm{ddd}, J=15.2,9.6,4.8 \mathrm{~Hz}, 1 \mathrm{H})$, 5.63-5.45 (m, 4H), $4.85(\mathrm{dt}, J=9.2,3.6 \mathrm{~Hz}, 1 \mathrm{H}), 4.15$ (brs, $1 \mathrm{H}), 3.99-3.84(\mathrm{~m}$, $5 \mathrm{H}), 3.60$ (brs, $1 \mathrm{H}), 3.24(\mathrm{dd}, J=4.4,2.8 \mathrm{~Hz}, 1 \mathrm{H}), 3.15(\mathrm{dd}, J=2.4,2.0 \mathrm{~Hz}$, $1 \mathrm{H}), 3.14-3.10(\mathrm{~m}, 1 \mathrm{H}), 2.70$ (brs, $1 \mathrm{H}), 2.56-2.43(\mathrm{~m}, 3 \mathrm{H}), 2.32-2.18(\mathrm{~m}, 4 \mathrm{H})$, $2.08(\mathrm{~s}, 3 \mathrm{H}), 2.02(\mathrm{~s}, 3 \mathrm{H}), 1.99-1.82(\mathrm{~m}, 5 \mathrm{H}), 1.74-1.69(\mathrm{~m}, 2 \mathrm{H}), 1.14$ $(\mathrm{d}, J=6.8 \mathrm{~Hz}, 3 \mathrm{H}), 0.97(\mathrm{~d}, J=7.2 \mathrm{~Hz}, 3 \mathrm{H}), 0.91(\mathrm{~d}, J=6.4 \mathrm{~Hz}, 3 \mathrm{H}) ;{ }^{13} \mathrm{C}-\mathrm{NMR}$ $\left(100 \mathrm{MHz}, \mathrm{CDCl}_{3}\right): \delta 169.0,144.2,141.8,135.8,130.9,129.1,129.0,128.3$, $124.5,76.3,76.2,72.4,71.0,70.9,62.2,55.9,55.1,41.4,38.2,37.1,36.6,36.1$, $35.9,34.54,34.50,16.5,16.3,15.6,13.7,11.4$; HR-MS (ESI) calcd. for $\mathrm{C}_{30} \mathrm{H}_{49} \mathrm{O}_{8}$ $\left[\mathrm{M}^{+}+\mathrm{H}\right]$ 537.3422, found 537.3413.

\section{Truncated analog 10}

$[\alpha]^{26}{ }_{\mathrm{D}}-8.3$ (c 0.11, $\mathrm{CHCl}_{3}$ ); IR (neat): 3406 (br), $1693 \mathrm{~cm}^{-1}$; ${ }^{1} \mathrm{H}-\mathrm{NMR}$ $\left(400 \mathrm{MHz}, \mathrm{CDCl}_{3}\right): \delta 7.30(\mathrm{~s}, 1 \mathrm{H}), 5.76(\mathrm{ddd}, J=15.2,10.0,5.2 \mathrm{~Hz}, 1 \mathrm{H})$, $5.63-5.46(\mathrm{~m}, 4 \mathrm{H}), 4.85(\mathrm{dt}, J=9.2,3.6 \mathrm{~Hz}, 1 \mathrm{H}), 4.15$ (brs, $1 \mathrm{H}), 3.85$ $(\mathrm{dt}, J=6.8,2.8 \mathrm{~Hz}, 1 \mathrm{H}), 3.71(\mathrm{~d}, J=4.8 \mathrm{~Hz}, 2 \mathrm{H}), 3.60$ (brs, $1 \mathrm{H}), 3.24$ (dd, $J=4.4,2.4 \mathrm{~Hz}, 1 \mathrm{H}), 3.15$ (dd, $J=2.4,2.0 \mathrm{~Hz}, 1 \mathrm{H}), 3.14-3.10(\mathrm{~m}, 1 \mathrm{H})$, 2.56-2.42 (m, 3H), 2.25-2.18 (m, 6H), $2.09(\mathrm{~s}, 3 \mathrm{H}), 2.04-1.84(\mathrm{~m}, 8 \mathrm{H}), 1.14$ $(\mathrm{d}, J=6.8 \mathrm{~Hz}, 3 \mathrm{H}), 0.95(\mathrm{~d}, J=6.8 \mathrm{~Hz}, 3 \mathrm{H}), 0.91(\mathrm{~d}, J=6.4 \mathrm{~Hz}, 3 \mathrm{H}) ;{ }^{13} \mathrm{C}-\mathrm{NMR}$ $\left(100 \mathrm{MHz}, \mathrm{CDCl}_{3}\right): \delta 168.9,144.1,141.7,135.8,131.0,129.1,128.9,128.3$, 124.6, 76.2, 73.7, 71.0, 70.9, 67.0, 55.9, 55.1, 38.8, 38.2, 37.6, 36.1, 35.9, 34.5, $16.5,16.3,15.6,13.7,10.3$; HR-MS (ESI) calcd. for $\mathrm{C}_{28} \mathrm{H}_{45} \mathrm{O}_{7}\left[\mathrm{M}^{+}+\mathrm{H}\right]$ 493.3160, found 493.3153 .

\section{Truncated analog 11}

$[\alpha]^{25} \mathrm{D}-13$ (c 0.12, $\mathrm{CHCl}_{3}$ ); IR (neat): 3414 (br), $1696 \mathrm{~cm}^{-1} ;{ }^{1} \mathrm{H}-\mathrm{NMR}$ $\left(400 \mathrm{MHz}, \mathrm{CDCl}_{3}\right): \delta 7.30(\mathrm{~s}, 1 \mathrm{H}), 5.76(\mathrm{ddd}, J=15.2,10.0,5.2 \mathrm{~Hz}, 1 \mathrm{H})$, $5.63-5.43(\mathrm{~m}, 4 \mathrm{H}), 4.85$ (dt, J=9.2, $3.6 \mathrm{~Hz}, 1 \mathrm{H}), 4.15$ (brs, $1 \mathrm{H}), 3.66$ $(\mathrm{t}, J=6.0 \mathrm{~Hz}, 2 \mathrm{H}), 3.60$ (brs, $1 \mathrm{H}), 3.24(\mathrm{dd}, J=4.8,2.4 \mathrm{~Hz}, 1 \mathrm{H}), 3.15$ (dd, $J=2.4,2.0 \mathrm{~Hz}, 1 \mathrm{H}), 3.14-3.08(\mathrm{~m}, 1 \mathrm{H}), 2.60-2.42(\mathrm{~m}, 3 \mathrm{H}), 2.33-2.18$ $(\mathrm{m}, 4 \mathrm{H}), 2.09(\mathrm{~s}, 3 \mathrm{H}), 2.02-1.86(\mathrm{~m}, 8 \mathrm{H}), 1.14(\mathrm{~d}, J=7.2 \mathrm{~Hz}, 3 \mathrm{H}), 0.91$ $(\mathrm{d}, J=6.4 \mathrm{~Hz}, 3 \mathrm{H}) ;{ }^{13} \mathrm{C}-\mathrm{NMR}\left(100 \mathrm{MHz}, \mathrm{CDCl}_{3}\right): \delta 168.9,144.0,141.7,135.8$, $130.7,129.1,128.7,128.2,124.6,76.2,71.0,70.9,62.1,55.9,55.1,38.2,36.10$, $36.06,35.9,34.53,34.49,16.5,16.2,15.6,13.7$; HR-MS (ESI) calcd. for $\mathrm{C}_{25} \mathrm{H}_{39} \mathrm{O}_{6}\left[\mathrm{M}^{+}+\mathrm{H}\right]$ 435.2741, found 435.2735.

\section{In vitro cytotoxic assay}

HeLa cells were cultured in Dulbecco's modified Eagle's medium supplemented with $10 \%$ fetal calf serum (Nichirei Biosciences, Tokyo, Japan) in a humidified atmosphere containing $5 \% \mathrm{CO}_{2}$. For viability assay, HeLa cells were seeded at $3 \times 10^{3}$ cells per $100 \mu \mathrm{l}$ per well in a 96-well microplate, and treated with various concentrations of FD-891 derivatives for $48 \mathrm{~h}$. IC $\mathrm{IC}_{50}$ values were determined using the cell counting reagent WST-8 (Dojindo, Kumamoto, Japan).

\section{CONFLICT OF INTEREST}

The authors declare no conflict of interest.

\section{ACKNOWLEDGEMENTS}

We acknowledge Prof. Masahiro Terada and Mr. Takuto Yamanaka (Graduate School of Science, Tohoku University) for kindly providing information on the organocatalytic allylation using catalyst $\mathbf{3 5}$. This work was supported by a Grant-in-Aid for Scientific Research on the Innovative Area 'Chemical Biology of Natural Products' from The Ministry of Education, Culture, Sports, Science and Technology, Japan (No. 23102013 to NK), and a Research Fellowship Grant for Young Researchers from Japan Society for the Promotion of Science (15J03635 to AK).

1 Seki-Asano, M. et al. Isolation and characterization of new 18-membered macrolides FD-891 and FD-892. J. Antibiot. 47, 1226-1233 (1994).

2 Seki-Asano, M., Tsuchida, Y., Hanada, K. \& Mizoue, K. Structures of new 18-membered macrolides FD-891 and FD-892. J. Antibiot. 47, 1234-1241 (1994).

3 Eguchi, T., Yamamoto, K., Mizoue, K. \& Kakinuma, K. Structure revision of FD-891, a 16-membered macrolide antibiotic. J. Antibiot. 57, 156-157 (2004).

4 Kataoka, T. et al. FD-891, a structural analogue of concanamycin A that does not affect vacuolar acidification or perforin activity, yet potently prevents cytotoxic $T$ lymphocytemediated cytotoxicity through the blockage of conjugate formation. Immunology 100 , 170-177 (2000).

5 Inaba, S. et al. The cytotoxic macrolide FD-891 induces caspase-8-dependent mitochondrial release of cytochrome $c$ and subsequent apoptosis in human leukemia Jurkat cells. J. Antibiot. 62, 507-512 (2009).

6 Kudo, F., Motegi, A., Mizoue, K. \& Eguchi, T. Cloning and characterization of the biosynthetic gene cluster of 16-membered macrolide antibiotic FD-891: involvement of a dual functional cytochrome P450 monooxygenase catalyzing epoxidation and hydroxylation. Chembiochem 11, 1574-1582 (2010).

7 Kudo, F. et al. Parallel post-polyketide synthase modification mechanism involved in FD-891 biosynthesis in Streptomyces graminofaciens A-8890. Chembiochem (e-pub ahead of print 2 December 2015; doi:10.1002/cbic.201500533).

8 Crimmins, M. T. \& Caussanel, F. Enantioselective total synthesis of FD-891. J. Am. Chem. Soc. 128, 3128-3129 (2006).

9 Garcia-Fortanet, J., Murga, J., Carda, M. \& Marco, J. A. Stereoselective synthesis of the cytotoxic macrolide FD-891. Org. Lett. 8, 2695-2698 (2006).

10 Yadav, J. S., Das, S. K. \& Sabitha, G. Stereoselective total synthesis of FD-891. J. Org. Chem. 77, 11109-11118 (2012).

11 Garcia-Fortanet, J. et al. The total synthesis and biological properties of the cytotoxic macrolide FD-891 and its non-natural (Z)-C12 isomer. Chem. Eur. J 13, 5060-5074 (2007).

12 Kanoh, N. et al. A concise and unified strategy for synthesis of the C1-C18 macrolactone fragments of FD-891, FD-892 and their analogues: formal total synthesis of FD-891. Org. Lett. 16, 5216-5219 (2014).

13 Drahl, C., Cravatt, F. \& Sorensen, E. J. Protein-reactive natural products. Angew. Chem. Int. Ed. 44, 5788-5809 (2005).

14 Sedrani, R. et al. Sanglifehrin-cyclophilin interaction: degradation work, synthetic macrocyclic analogues, X-ray crystal structure, and binding data. J. Am. Chem. Soc. 125, 3849-3859 (2003).

15 Wakamiya, T., Konishi, K., Chaki, H., Teshima, T \& Shiba, T. Chemical studies on tuberactinomycin. XVIII. Syntheses of DL-dihydroviomycidine and DL-viomycidine. Heterocycles 15, 999-1005 (1981).

16 Chandrasekhar, B., Athe, S., Reddy, P. P. \& Ghosh, S. Synthesis of fully functionalized aglycone of lycoperdinoside A and B. Org. Biomol. Chem. 13, 115-124 (2015).

17 Brown, H. C., Bhat, K. S. \& Randad, R. S. Chiral synthesis via organoboranes. 21. Allylboration and crotylboration of alpha-chiral aldehydes with diisopinocampheylboron as the chiral auxiliary. J. Org. Chem. 54, 1570-1576 (1989).

18 Fuwa, H. \& Sasaki, M. Total synthesis of (-)-exiguolide. Org. Lett. 12 584-587 (2010).

19 Rychnovsky, S. D., Rogers, B. \& Yang, G. Analysis of two ${ }^{13} \mathrm{C}$ NMR correlations for determining the stereochemistry of 1,3-diol acetonides. J. Org. Chem. 58, 3511-3515 (1993).

20 Lee, J., Kobayashi, Y., Tezuka, K. \& Kishi, Y. Toward creation of a universal NMR database for the stereochemical assignment of acyclic compounds: proof of concept. Org. Lett. 1, 2181-2184 (1999).

21 Jain, P. \& Antilla, J. C. Chiral Brønsted acid-catalyzed allylboration of aldehydes. J. Am. Chem. Soc. 132, 11884-11886 (2010).

22 Shirokawa, S. I. et al. Remote asymmetric induction with vinyl ketene silyl N,O-acetal. J. Am. Chem. Soc. 126, 13604-13605 (2004).

23 Sasano, Y., Kogure, N., Nishiyama, T., Nagasawa, S. \& Iwabuchi, Y. Highly efficient aerobic oxidation of alcohols by using less-hindered nitroxyl-radical/copper catalysis: optimum catalyst combinations and their substrate scope. Chem. Asian J. 10, 1004-1009 (2015).

Supplementary Information accompanies the paper on The Journal of Antibiotics website (http://www.nature.com/ja) 